\title{
Potency of Dioscorea sansibarensis (Dioscoreaceae) Leaf Eluates on Callosobruchus chinensis, Linnaeus 1758 (Coleoptera: Bruchidae) in the Protection of Phaseolus vulgaris (Fabaceae)
}

\author{
Godfrey O. Mauti \\ Department of Physical and Biological Science, School of Pure and Applied Sciences, Bomet \\ University College, Bomet, Kenya. E-mail: gomare@buc.ac.ke
}

Received 28 Jul 2021, Revised 31 Aug 2021, Accepted 31 Aug 2021, Published Aug 2021

DOI: https://dx.doi.org/10.4314/tjs.v47i3.40

\begin{abstract}
Post-harvest losses of stored Phaseolus vulgaris to the bean weevil Callosobruchus chinensis have reached levels of significant concern. Governments and health organisations propose the discovery of reliable, healthy and biodegradable pesticides with higher selectivity and a broad spectrum. This study presents investigations on the activities of Dioscorea sansibarensis leaf extracts on the mortality of $C$. chinensis and reduction of their egg-laying ability. Laboratory experiments under Completely Randomized Design (CRD) were carried out to determine the mortality and antioviposition activity of the vacuum liquid chromatography (VLC) eluates of $n$-hexane (HE), chloroform (CE), ethyl acetate (EE), $n$-butanol (BE) and methanol (BE) at different concentrations. Bioassay data were subjected to nonparametric statistical analysis and a generalized linear model at $p=0.05$. Statistical results showed that the VLC eluates had a mortality activity of $88.01 \%\left(\mathrm{R}^{2}=0.8801\right)$. Treatment by $0.025 \mathrm{~g}$ of HE and $0.075 \mathrm{~g}$ of CE had 9.60 and 11.50 , respectively at $p=0.181$. These mortality records were high as to $0.1 \mathrm{~g}$ of ME, $0.05 \mathrm{~g}$ of EE and $0.075 \mathrm{~g}$ of $\mathrm{BE}$ that recorded $8.55,8.45$ and 7.80, respectively. Treatments by 0.05 $\mathrm{g}$ of $\mathrm{CE}, 0.025 \mathrm{~g}$ of HE, $0.05 \mathrm{~g}$ of EE and the positive control recorded mortality of 10.50, 9.60, 8.45 and 8.35 , respectively. The highest mortality was observed in the treatment by $0.075 \mathrm{~g}$ of HE and $0.1 \mathrm{~g}$ of HE with 12.85 and 13.70 , respectively at $p=0.377$. The VLC eluates had an antioviposition activity of $24.98 \%\left(\mathrm{R}^{2}=0.2498\right)$ on the $C$. chinensis. The generalized linear model reported Wald Chi-Square values of 4.363; $p=0.037,0.711 ; p=0.399,9.125 ; p=0.003,4.363 ; p$ $=0.037$ on the treatment by $0.025 \mathrm{~g}$ of CE, $0.05 \mathrm{~g}$ of EE, $0.075 \mathrm{~g}$ of BE and $0.1 \mathrm{~g}$ of ME, respectively. At $p=0.051,0.1 \mathrm{~g}$ of $\mathrm{CE}$ and the positive control attained oviposition of 89.25 and 96.75 respectively. The study presents the first documentation of the lethal activity of $D$. sansibarensis on the $C$. chinensis pulse beetle. This could help in the development of Integrated Pest Management (IPM) and could help in the elimination or suppression of the infestation.
\end{abstract}

Keywords: anti-oviposition, Callosobruchus chinensis, Dioscorea sansibarensis leaf, mortality, Phaseolus vulgaris, vacuum liquid chromatography (VLC) eluates.

\section{Introduction}

In recent years, losses of stored Phaseolus vulgaris (common bean) to Callosobruchus chinensis LINNAEUS, 1758 (Coleoptera: Bruchidae) in the tropics have reached levels of significant concern (Mishra et al. 2018). An increase in damage by the bruchids is due to farmers being mindful of the environmental and health hazards posed by synthetic pesticides and the ban of synthetic insecticides with undegradable toxins by the governments and health organisations (Iram et al. 2013). 
These hazards have intensified the need to discover reliable, healthy and biodegradable pesticides with higher selectivity and a broad spectrum. Substitute approaches have led to reevaluation and use of botanical insecticides either as crude or formulated extracts as control agents (Babarinde et al. 2018, Kishor and Tiwari 2021).

Plants are a rich source of natural products, and many plant species synthesize their chemicals and store them in different parts of the plants. Plant compounds are easy to extract using different solvents. Crude extracts of plants are fractionated using vacuum liquid chromatography (VLC) with various solvents with varying polarity and solubility and appear in the form of slurries, powder or shredded segments (Targett et al. 1979). Ethanol, ethyl acetate and chloroform VLC elute of Melia azedarach, and Aphanamixis polystachya were found to cause mortality and reduction in the number of laid eggs, and this was due to the presence of compounds with insecticidal properties (Odeyemi et al. 2008, Hernández et al. 2017, Uyi et al. 2020).

Research shows that different organs of a plant have different phytochemicals with different concentrations, hence may exert different effects on insect pests. Shukla et al. (2009) reported that methanol and petroleum ether crude eluates of leaf and rhizome of Acorus calamus (sweet flag), caused adult mortality and adversely affected the adult emergence of the $C$. chinensis (Mots). According to Bekele (2002), crude eluates from leaf, pod and bark of Millettia ferruginea (Hochest) using distilled water, petroleum ether, acetone, $n$-hexane, methanol and ethanol exhibited anti-oviposition of the Sitophilus zeamais.

According to Kumar et al. (2017), the bioactive compounds present in the vegetative parts of the Dioscorea sansibarensis plant are not well exposed even though all parts, i.e., leaf, underground tuber, aerial bulbil and stem are found to be toxic to the herbivores and the insects of the family Chrysomelidae. Studies by Price et al. (2016a) reported the presence of the phytochemical compounds phytol, 1-epi-agurjunene, palmitic acid, ethyl palmitate, methyl palmitate, isophytol, 2-heptadecanone and a-selinene in D. sansibarensis leaf with antibacterial effects. This study presents investigations on the activities of $D$. sansibarensis leaf eluates by vacuum liquid chromatography technique on the mortality of Callosobruchus chinensis and reduction of their egg-laying ability.

\section{Materials and Methods}

The materials and methods are summarised in Figure 1.

\section{Preparation of materials}

Fresh leaves of $D$. sansibarensis were identified and harvested in April 2019 from the Zoology-Botany Forest thickets at the University of Dar es Salaam located at $6^{\circ} 45^{\prime} 0^{\prime \prime}$ $\mathrm{S}$ by $39^{\circ} 15^{\prime} 0^{\prime \prime} \mathrm{E}$, altitude $80 \mathrm{~m}$ above sea level. Morphological identification was done at the Botany Department's herbarium, University of Dar es Salaam, where voucher specimen bearing reference number FMM 3910a was deposited. The plant material was properly washed with tap water, rinsed with distilled water and left to dry under shade in a wellventilated area in the Entomology Laboratory of the Department of Zoology and Wildlife Conservation, University of Dar es Salaam.

Dry D. sansibarensis leaves were macerated and stored separately in airtight containers and stored at room temperature for experimental use. Healthy and undamaged $P h$. vulgaris bean seeds were purchased directly from Kisarawe farm $\left(7^{\circ} 10^{\prime} 0^{\prime \prime} \mathrm{S}, 38^{\circ} 50^{\prime} 0^{\prime \prime} \mathrm{E}\right.$ and altitude of $252 \mathrm{~m}$ above sea level) after harvest. The seeds were sun-dried and stored at room temperature with $10 \pm 2 \%$ moisture content for experimentation. The analytical grade solvents; $n$-hexane, chloroform, ethyl acetate $n$ - butanol, methanol for use in vaccum liquid chromatography (VLC) and the standard synthetic pesticide; Actellic 50 EC $(500 \mathrm{~g} / \mathrm{L}$ AI, $100 \mathrm{~g} / 90 \mathrm{~kg}$ Syngenta, Switzerland) were purchased from Chem equip laboratory suppliers in Tanzania. 


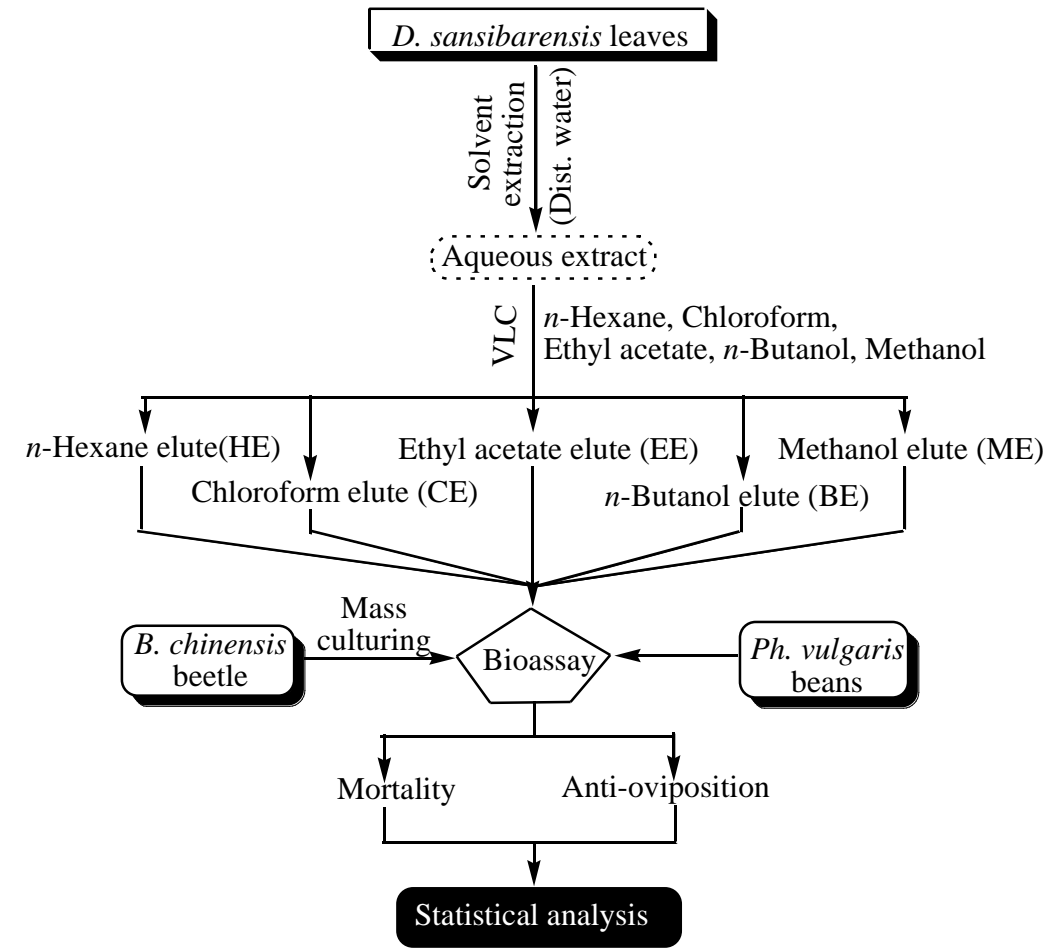

Key:

VLC - Vacuum liquid chromatography

Figure 1: Summary of the study methodology.

Vacuum liquid chromatography of plant materials

From the powder of $D$. sansibarensis leaves, $110 \mathrm{~g}$ was weighed and soaked in $500 \mathrm{~mL}$ of methanol at $27{ }^{\circ} \mathrm{C}$ for two days. The solution was percolated through Whatman no. 1 filter paper then concentrated to dryness at $40{ }^{\circ} \mathrm{C}$. The dry methanol extract was weighed and subjected to fractionation in vacuum liquid chromatography (VLC) using $n$-hexane, chloroform, ethyl acetate, $n$-butanol and methanol solvents. The VLC eluates were collected separately as fractions and dried using a rotary evaporator at $40{ }^{\circ} \mathrm{C}$ (Targett et al. 1979).

\section{Preparation of working concentrations}

Working solutions with different concentrations were prepared by diluting 0.025 , $0.05,0.075$ and $0.1 \mathrm{~g}$ of VLC elute of the $D$. sansibarensis leaves in $5 \mathrm{~mL}$ of their respective fractionating solvents to give respective concentrations of $0.036,0.072,0.108$ and 0.144 $\mathrm{mg} / \mathrm{mL}$. Following the manufacturer's instructions, Actellic 50 EC was used as the standard positive control by diluting $2.5 \mathrm{~g}$ in 5 $\mathrm{mL}$ of water to give a concentration of 0.02 $\mathrm{mg} / \mathrm{mL}$. These doses were applied on $50 \mathrm{~g}$ of $P h$. vulgaris beans for bioassays. The bean seeds to be used as negative control (untreated seeds) were cleaned and dried in a hot air oven at $60{ }^{\circ} \mathrm{C}$ for 1 hour.

\section{Stock culture of Callosobruchus chinensis}

In a glass jar $(10.3 \mathrm{~cm}$ wide and $15 \mathrm{~cm}$ depth) containing $350 \mathrm{~g}$ of dry and undamaged $P h$. vulgaris beans, approximately 200 females and males of $C$. chinensis were placed and the mouth was covered with a muslin cloth. The jar was incubated for 1 week in darkness at $28 \pm 2$ 
${ }^{\circ} \mathrm{C}$ and relative humidity of $65 \pm 5 \%$ to facilitate egg-laying by the $C$. chinensis. The bruchids were removed and the beans were incubated for mass culturing of the $F_{1}$ progeny of $C$. chinensis. The pure culture of the $\mathrm{F}_{1}$ breed was used in experimentation.

\section{Assays for adult mortality}

Fifty grams $(50 \mathrm{~g})$ of clean, disinfected common bean seeds were weighed into different sterilized glass bottles and mix properly with VLC extracts of the leaf. Ten pairs of newly emerged adult weevils were introduced into the treated legumes in glass bottles and covered with a muslin cloth. Each treatment was replicated four times and arranged in a Completely Randomized Design (CRD) on a laboratory bench. Mortality was determined by the number of dead insects which were recorded every 24 hours for ten days and computed using the formula adopted by Hasan et al. (2020).

\section{Assays for anti-oviposition}

Ten pairs of $C$. chinensis beetles were subjected to glass jars containing treated seeds and controls. The containers were incubated in the dark at $28 \pm 2^{\circ} \mathrm{C}$ with a relative humidity of $65 \pm 5 \%$ for egg-laying by the weevils. On the $5^{\text {th }}$ day of incubation, all weevils, dead or alive, were removed from each container. Eggs laid on the bean seeds were counted with the aid of a dissecting microscope and computed using the formula adopted by Mauti et al. (2020).

\section{Statistical analyses}

Mortality and anti-oviposition analyses were performed using the SPSS software (version 20). The analysis involved the determination of Poisson distribution by nonparametric (Kolmogorov-Smirnov) test and descriptive statistics of the mean-variance. The Poisson distributed data from the mortality and antioviposition were subjected separately to generalized linear model analysis at $p=0.05$.
In the model of analyzing the mortality and anti-oviposition, the concentrations of the doses were the independent variables as data of mortality and anti-oviposition were the dependent variable.

\section{Results}

\section{Adult mortality of $C$. chinensis}

Tabulated results of the lowest dosage showed mortality was high in the treatment by hexane elute, i.e., $0.025 \mathrm{~g}$ of $\mathrm{HE}, \mathrm{CE}$ and $\mathrm{EE}$ recorded mortality of $3.0,1.75$ and 0.50 , respectively as $0.025 \mathrm{~g}$ of $\mathrm{BE}$ and $\mathrm{ME}$ had no mortality effect on the bruchids (Table 1). Data subjected to statistical analysis $(\mathrm{N}=440)$ showed a Poisson distribution; the Kolmogorov-Smirnov test recorded 4.441 and the descriptive statistics recorded a mean of 8.49 with a variance of 31.417 . Statistically, mortality increased with days of exposure, i.e., harmonic mortality on the $1^{\text {st }}$ day, $2^{\text {nd }} 3^{\text {rd }}, 4^{\text {th }}$ and $5^{\text {th }}$ day were $3.30,5.99,8.40,11.25$ and 13.93, respectively. The VLC eluates had a mortality activity of $88.01 \%\left(\mathrm{R}^{2}=0.8801\right)$ on the $C$. chinensis where the treatment by $0.025 \mathrm{~g}$ of $\mathrm{HE}$ and $0.075 \mathrm{~g}$ of $\mathrm{CE}$ had 9.60 and 11.50, respectively at $p=0.181$. These mortality records were high as to $0.1 \mathrm{~g}$ of $\mathrm{ME}, 0.05 \mathrm{~g}$ of $\mathrm{EE}$ and $0.075 \mathrm{~g}$ of $\mathrm{BE}$ that recorded $8.55,8.45$ and 7.80 , respectively.

The generalized linear model reported a Wald Chi-Square value of $1.022 ; p=0.312$, $0.630 ; p=0.427, \quad 1.453 ; p=0.228$ and $0.813 ; p=0.367$ in the treatment by the positive control, $0.025 \mathrm{~g}$ of $\mathrm{HE}, 0.05 \mathrm{~g}$ of $\mathrm{CE}$ and $0.05 \mathrm{~g}$ of EE, respectively. Treatments by $0.05 \mathrm{~g}$ of CE, $0.025 \mathrm{~g}$ of $\mathrm{HE}$ and $0.05 \mathrm{~g}$ of EE recorded mortality of $10.50,9.60$ and 8.45, respectively which were high to the positive control that had 8.35. The highest mortality was observed in the treatment by $0.075 \mathrm{~g}$ of $\mathrm{HE}$ and $0.1 \mathrm{~g}$ of $\mathrm{HE}$ with 12.85 and 13.70, respectively at $p=0.377$. 
Mauti - Potency of Dioscorea sansibarensis (Dioscoreaceae) Leaf Eluates on C. chinensis ...

Table 1: Mortality of C. chinensis reared for 5 days on Ph. vulgaris treated with VLC eluates of D. sansibarensis leaves

\begin{tabular}{|c|c|c|c|c|c|c|}
\hline \multirow{2}{*}{$\begin{array}{l}\text { VLC eluates } \\
\text { of } D . \\
\text { sansibarensis } \\
\text { leaves }\end{array}$} & \multirow{2}{*}{$\begin{array}{c}\text { Conc. } \\
\text { (g/50 } \\
\mathrm{g} \text { of } \\
\text { beans) } \\
\end{array}$} & \multicolumn{5}{|c|}{ Mortality at days after treatment (Mean \pm S.E.) } \\
\hline & & Day 1 & Day 2 & Day 3 & Day 4 & Day 5 \\
\hline \multirow{4}{*}{$\begin{array}{l}n \text {-Hexane } \\
\text { elute (HE) }\end{array}$} & 0.025 & $3.0 \pm 0.41^{\mathrm{w}}$ & $6.0 \pm 0.40^{\mathrm{s}}$ & $9.25 \pm 0.481$ & $13.0 \pm 0.71^{\mathrm{e}}$ & $16.75 \pm 0.48^{b}$ \\
\hline & 0.05 & $5.0 \pm 0.82^{\mathrm{u}}$ & $\begin{array}{c}8.0 \pm 0.91^{\mathrm{n}} \\
1075+\end{array}$ & $12.0 \pm 0.41^{\mathrm{f}}$ & $16.0 \pm 1.08^{\mathrm{d}}$ & $19.0 \pm 0.40$ \\
\hline & 0.075 & $7.0 \pm 1.08^{q}$ & $0.85^{\mathrm{h}}$ & $14.0 \pm 0.41^{\mathrm{d}}$ & $17.0 \pm 0.71^{\mathrm{b}}$ & $19.75 \pm 0.25^{\mathrm{a}}$ \\
\hline & 0.1 & $7.75 \pm 1.25^{\mathrm{n}}$ & $12.25 \pm 0.85^{\mathrm{f}}$ & $14.75 \pm 0.75^{\mathrm{d}}$ & $17.75 \pm 0.85^{\mathrm{b}}$ & $20.0 \pm 0.00^{\mathrm{a}}$ \\
\hline \multirow{4}{*}{$\begin{array}{l}\text { Chloroform } \\
\text { elute (CE) }\end{array}$} & 0.025 & $1.75 \pm 0.85^{\mathrm{z}}$ & $3.25 \pm 0.48^{\mathrm{w}}$ & $6.0 \pm 0.58^{s}$ & $9.0 \pm 0.41^{\mathrm{m}}$ & $13.0 \pm 0.91^{\mathrm{e}}$ \\
\hline & 0.05 & $5.25 \pm 0.85^{\mathrm{t}}$ & $7.50 \pm 0.87^{\circ}$ & $10.75 \pm 0.85^{\mathrm{h}}$ & $13.0 \pm 0.82^{\mathrm{e}}$ & $16.0 \pm 1.08^{\mathrm{d}}$ \\
\hline & 0.075 & $6.0 \pm 0.71^{\mathrm{s}}$ & $9.0 \pm 0.41^{\mathrm{m}}$ & $12.0 \pm 0.71^{\mathrm{f}}$ & $14.25 \pm 0.63^{\mathrm{d}}$ & $16.25 \pm 0.85^{\mathrm{c}}$ \\
\hline & 0.1 & $7.0 \pm 0.82^{\mathrm{q}}$ & $9.75 \pm 0.48^{j}$ & $13.75 \pm 0.85$ & $15.75 \pm 0.75^{\mathrm{d}}$ & $17.0 \pm 0.91^{\mathrm{b}}$ \\
\hline \multirow{4}{*}{$\begin{array}{l}\text { Ethyl acetate } \\
\text { elute (EE) }\end{array}$} & 0.025 & $0.50 \pm 0.50^{\mathrm{z}}$ & $2.0 \pm 0.41^{\mathrm{y}}$ & $4.25 \pm 0.85^{\mathrm{v}}$ & $8.75 \pm 1.03^{\mathrm{m}}$ & $13.0 \pm 0.91^{\mathrm{e}}$ \\
\hline & 0.05 & $2.25 \pm 0.48^{x}$ & $5.75 \pm 1.11^{\mathrm{s}}$ & $9.25 \pm 1.311$ & $11.0 \pm 1.22$ & $14.0 \pm 0.82^{\mathrm{d}}$ \\
\hline & 0.075 & $5.75 \pm 1.25^{\mathrm{s}}$ & $8.50 \pm 0.96$ & $11.75 \pm 1.03$ & $13.25 \pm 1.31^{\mathrm{e}}$ & $16.0 \pm 1.47^{\mathrm{d}}$ \\
\hline & 0.1 & $5.75 \pm 0.85^{\mathrm{s}}$ & $9.75 \pm 1.25^{\mathrm{j}}$ & $13.0 \pm 1.02^{\mathrm{e}}$ & $16.0 \pm 0.82^{\mathrm{d}}$ & $19.75 \pm 0.25^{\mathrm{a}}$ \\
\hline \multirow{4}{*}{$\begin{array}{l}n \text {-Butanol } \\
\text { elute (BE) }\end{array}$} & 0.025 & $0.00 \pm 0.00$ & $0.75 \pm 0.48^{\mathrm{z}}$ & $2.75 \pm 0.48$ & $6.25 \pm 1.11^{\mathrm{r}}$ & $10.0 \pm 0.71^{\mathrm{i}}$ \\
\hline & 0.05 & $0.50 \pm 0.29^{\mathrm{z}}$ & $3.0 \pm 0.41^{\mathrm{w}}$ & $6.0 \pm 1.08^{\mathrm{s}}$ & $9.50 \pm 0.65^{\mathrm{k}}$ & $12.25 \pm 1.11^{\mathrm{f}}$ \\
\hline & 0.075 & $3.25 \pm 0.63^{w}$ & $5.25 \pm 0.48^{t}$ & $7.50 \pm 0.65^{\circ}$ & $10.0 \pm 0.41^{\mathrm{i}}$ & $13.0 \pm 1.08^{\mathrm{e}}$ \\
\hline & 0.1 & $4.25 \pm 0.85^{\mathrm{v}}$ & $6.25 \pm 0.85^{\mathrm{r}}$ & $9.0 \pm 0.82^{\mathrm{m}}$ & $12.75 \pm 1.11^{\mathrm{f}}$ & $14.25 \pm 0.85^{\mathrm{d}}$ \\
\hline \multirow{4}{*}{$\begin{array}{l}\text { Methanol } \\
\text { elute (ME) }\end{array}$} & 0.025 & $0.00 \pm 0.00$ & $0.00 \pm 0.00$ & $2.0 \pm 0.41^{\mathrm{y}}$ & $5.0 \pm 0.91^{\mathrm{u}}$ & $7.25 \pm 1.03^{\mathrm{p}}$ \\
\hline & 0.05 & $0.25 \pm 0.25^{\mathrm{z}}$ & $2.0 \pm 0.41^{y}$ & $4.0 \pm 0.41$ & $6.75 \pm 0.48$ & $9.25 \pm 0.85^{1}$ \\
\hline & 0.075 & $2.0 \pm 0.71^{y}$ & $3.75 \pm 0.84$ & $6.50 \pm 0.65$ & $9.50 \pm 0.65^{\mathrm{k}}$ & $9.25 \pm 2.78^{1}$ \\
\hline & 0.1 & $3.0 \pm 0.82^{\mathrm{w}}$ & $5.0 \pm 1.08^{\mathrm{u}}$ & $9.0 \pm 1.08^{\mathrm{m}}$ & $11.50 \pm 0.65^{\mathrm{g}}$ & $14.25 \pm 0.85^{\mathrm{d}}$ \\
\hline \multirow{3}{*}{$\begin{array}{l}\text { Actellic } 50 \\
\text { EC } \\
\text { Negative } \\
\text { control }\end{array}$} & & & & & & \\
\hline & 0.05 & $2.25 \pm 1.03^{x}$ & $4.50 \pm 1.04^{\mathrm{v}}$ & $7.25 \pm 0.63^{p}$ & $11.50 \pm 0.50^{\mathrm{g}}$ & $16.25 \pm 1.38^{c}$ \\
\hline & 0 & $0.00 \pm 0.00$ & $0.00 \pm 0.00$ & $0.00 \pm 0.00$ & $0.00 \pm 0.00$ & $0.25 \pm 0.25$ \\
\hline
\end{tabular}

Treatment with Poisson distributed data was subjected to a generalized linear model. The means in the table that do not share a letter are significantly different $(\mathrm{N}=440 ; p \leq 0.05)$.

Anti-oviposition activity of VLC eluates of D. sansibarensis leaves against $\mathrm{C}$. chinensis Graphic results showed that $0.025 \mathrm{~g}$ of ME had an anti-oviposition of $457.5 \mathrm{~g}$ and HE recorded $142.75 \mathrm{~g}$ (Figure 1). When the eggs laid on the treated seeds are equated to the eggs laid on the negative control (untreated seeds), $0.025 \mathrm{~g}$ of ME, EE, CE and HIM an anti-oviposition of $25.15 \%, 41.92 \%, 51.69 \%$ and $76.65 \%$, respectively. $0.1 \mathrm{~g}$ of $\mathrm{ME}$ and $0.025 \mathrm{~g}$ of $\mathrm{CE}$ showed a similar anti-oviposition of $57.51 \%$
(Figure 2). Data subjected to statistical analysis $(\mathrm{N}=88)$ showed a Poisson distribution; the Kolmogorov-Smirnov test recorded 4.313 and the descriptive statistics recorded a mean of 239.53 with a variance of 22351.148. The VLC eluates had an anti-oviposition activity of $24.98 \%\left(\mathrm{R}^{2}=0.2498\right)$ on the $C$. chinensis. The generalized linear model reported Wald ChiSquare values of $4.363 ; p=0.037,0.711 ; p=$ $0.399,9.125 ; p=0.003,4.363 ; p=0.037$ on the treatment by $0.025 \mathrm{~g}$ of $\mathrm{CE}, 0.05 \mathrm{~g}$ of $\mathrm{EE}$, $0.075 \mathrm{~g}$ of BE and $0.1 \mathrm{~g}$ of ME, respectively. 


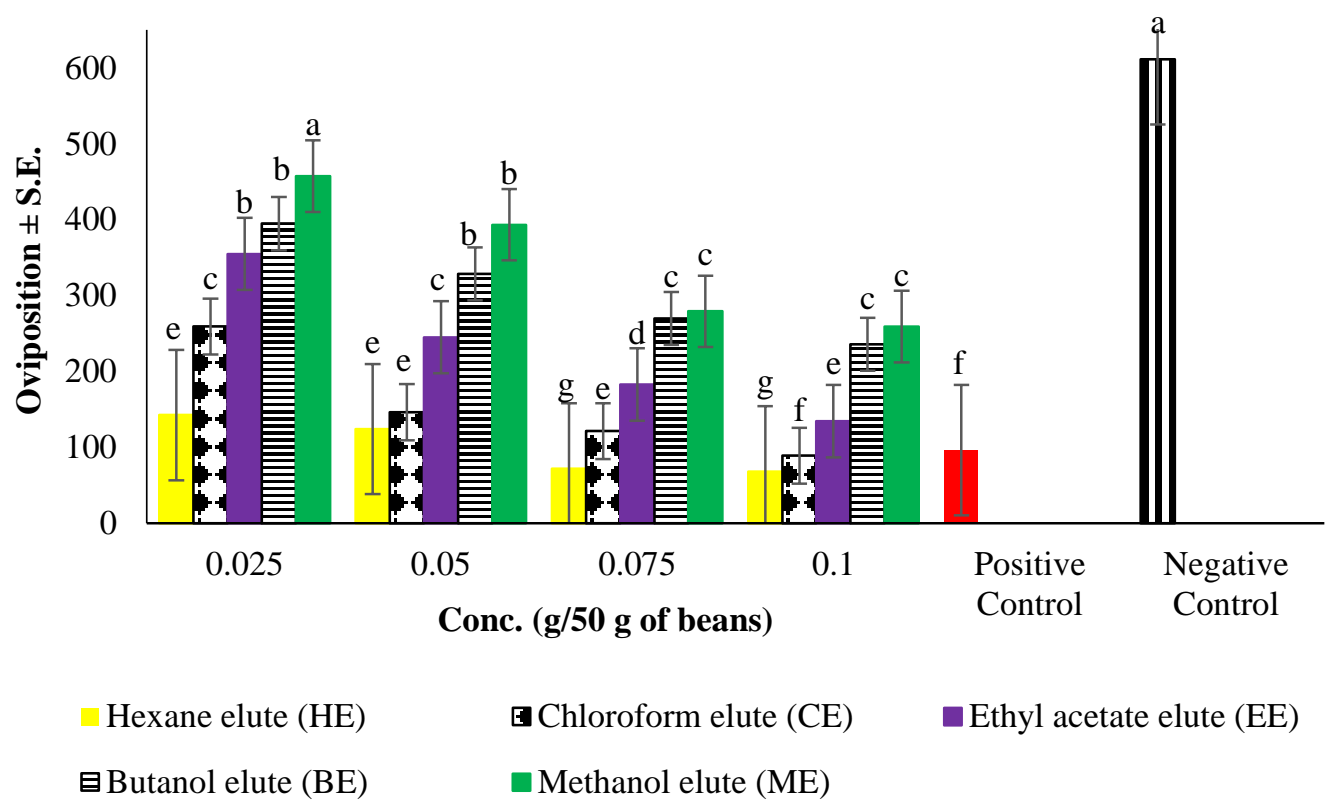

Figure 2: Oviposition by $C$. chinensis on Ph. vulgaris seeds treated with vacuum liquid chromatography (VLC) eluates of $D$. sansibarensis leaves. Means in the graph that do not share a letter are significantly different $(\mathrm{N}=88 ; p \leq 0.05)$.

Treatment by $0.075 \mathrm{~g}$ of CE and $0.025 \mathrm{~g}$ of HE had oviposition of $121.5 \mathrm{~g}$ and 142.8, respectively at $p=0.103$. These oviposition results were comparatively lower to 163.0 , 259.3 and 236.0 obtained by $0.075 \mathrm{~g}$ of EE, 0.1 $\mathrm{g}$ of $\mathrm{ME}$ and $0.1 \mathrm{~g}$ of $\mathrm{BE}$, respectively. At $p=$ $0.051,0.1 \mathrm{~g}$ of $\mathrm{CE}$ and the positive control attained oviposition of 89.25 and 96.75, respectively which were higher than the eggs counted in the treatment by $0.075 \mathrm{~g}$ of $\mathrm{HE}$ (72.25). A recommendable anti-oviposition effect was displayed by the hexane extract as observed in the treatment by $0.1 \mathrm{~g}$ of $\mathrm{HE}$ (32.50) as the lowest anti-oviposition effects were recorded by the methanol extracts.

\section{Discussion}

The results in this study showed that $D$. sansibarensis leaves were effective by causing mortality, anti-oviposition and reduced emergence of the $F_{1}$ progeny from the bean weevils. These results were similar to the findings reported by Mauti et al. (2019a) on the essential oil derived from D. sansibarensis leaves that caused mortality, anti-oviposition and reduced the number of emerging $C$. chinensis weevils from $P h$. vulgaris bean seeds. Various researches have shown that the leaf of a plant is a repository of compounds with diverse functions and activities on bean weevils including mortality and prevention of egg-laying on the common beans ( Uyi et al. 2020).

The aromatic and antifeedant nature of VLC elute of hexane of $D$. sansibarensis to leaf-feeding insects of the families Chrysomelidae, Curculionidae and Meloidae suggest that it may contain constituents that are highly effective against been weevils. Terpenoids, flavonoids and saponins identified by thin-layer chromatography in $D$. sansibarensis were responsible for the antioviposition and Inhibition of $\mathrm{F}^{1}$ emergence of C. chinensis (Mauti et al. 2020). According to Mauti et al. (2019b) and Philbert (2021), the common factors affecting the bioactivity and 
properties of a compound is the part of a plant that is extracted and the solvent used for extraction. Volatile and active compounds in plants extracted by hexane solvent have shown deterrent and toxic properties to $C$. chinensis weevils (Bubalo 2018).

In this study, $n$-hexane was used as a nonpolar solvent and its elute of the $D$. sansibarensis leaves portrayed deterrent activities in mortality and anti-oviposition of $C$. bruchus. This is similar to the findings by Danga et al. (2015), which revealed the hexane eluates of Callistemon rigidus leaves showed mortality and anti-oviposition of Callosobruchus maculatus on cowpea seeds as compared to the chloroform, ethyl acetate and methanol eluates.

Results obtained for hexane elute of $D$. sansibarensis in this study agree with previous results recorded by Shukla et al. (2009) on the hexane extract of A. calamus, whereby a dose of $0.04 \mathrm{~g}$ caused $92.4 \%$ of mortality and $93.5 \%$ inhibition of oviposition on chicken pea seeds. These results were slightly encouraging compared to methanol extracts of A. calamus leaf. A study by Javaid et al. (2020) on the hexane elute of Cenchrus setigerus leaves applied on cowpea seeds recorded a $25 \%$ mortality within 24 hours and $87.25 \%$ of antioviposition by $C$. maculatus.

In this study, chloroform eluates of the $D$. sansibarensis leaves showed mortality of the C. chinensis beetle, this was contrary to fidings of studies made by Mondal and Islam (2008) on $C$. maculatus. They recorded no mortality was observed in treatments by chloroform extract of Derris indica leaves; this difference might have been influenced by the phytochemical constituents presents in $D$. sansibarensis and absent in D. indica. Observation on the methanol elute of $D$. sansibarensis leaves showed low mortality of the beetle. This finding was similar to results obtained by Mustary et al. (2020) on Bruchus pisorum using methanol extract of Artocarpus heterophyllus leaves where the methanol eluates showed mortality properties. The similarity in results might be due to the presence of similar phytochemical compound(s) with similar composition(s) more so, using a precise solvent in the extraction of the compound(s). Based on the findings in the present investigations, it is recommended that the exploitation of the hexane eluates of $D$. sansibarensis leaves in the development of Integrated Pest Management (IPM) is a feasible control method in elimination or suppression of the infestation of bruchids.

\section{Acknowledgement}

The author would like to express his gratitude to DAAD-NAPRECA and the German embassy for the study scholarship [Reference number 91560175] for the research topic "Deterrent properties of Dioscorea sansibarensis (Dioscoreaceae) on Callosobruchus chinensis Linnaeus, 1758 (Bruchidae) in the protection of stored Phaseolus vulgaris (Fabaceae)". I am grateful to Mr. Frank Mbago of the Botany Departmental Herbarium for identifying the Dioscorea sansibarensis plant material, and to Mr. Emmanuel Fredrick of the Chemistry Department and Mr. Halima Mfaume of the Department of Zoology and Wildlife Conservation, University of Dar es Salaam, for their help as laboratory technicians.

\section{Declaration of interest}

The author declares no potential conflict of interest.

\section{References}

Babarinde SA, Kemabonta KA, Aderanti IA, Kolawole FC and Adeleye AD 2018 Synergistic effect of spinosad with selected botanical powders as bio-rational insecticides against adults of Tribolium castaneum Herbst, 1797 (Coleoptera: Tenebrionidae). J. Agric.Sci. 63(1): 39-51.

Bekele J 2002 Evaluation of the toxicity potential of Milletia ferruginea (Hochest) Baker against Sitophilus zeamais (Motsch.). Int. J. Pest Manag. 48(1): 29-32.

Bubalo MC, Vidović S, Redovniković IR and Jokić S 2018 New perspective in the extraction of plant biologically active compounds by green solvents. Food Bioprod. Process. 109(1): 52-73. 
Danga SPY, Nukenine EN, Younoussa L, Adler C and Esimone CO 2015 Efficacy of Plectranthus glandulosus (Lamiaceae) and Callistemon rigidus (Myrtaceae) leaf extract fractions to Callosobruchus maculatus (Coleoptera: Bruchidae). J. Insect Sci. 15(3): 139-152.

Hasan MAM, Sultana S, Akter K, Wara TU, Hasan $M$ and Uddin MM 2020 Biorational management of pulse beetle (Callosobruchus chinensis L.) in gram seed. Asian Plant Res. J. 6(2): 14-22.

Hernández HAB, Alarcón AFJ, Jiménez EM, Hernández PLB, Flores OCM, Rodríguez MA and Canales MM 2017 Biological properties and chemical composition of Jatropha neopauciflora pax. Afr. J. Tradit. Complem. 14(1): 32-42.

Iram N, Arshad M and Akhter N 2013 Evaluation of botanical and synthetic insecticide for the control of Tribolium castaneum (Herbst) (Coleoptera: Tenebrionidae). Bioassay 8(3): 110.

Javaid A, Amin M and Khan IH 2020 Identification of phytochemicals of Syzygium cumini fruit. Int. J. Biol. Biotech. 17(3): 497-501.

Kishor K and Tiwari BMR 2021 Effect of cow dung smoke on pulse beetle, Callosobruchus chinensis (Linn.) and quality parameters of stored pulses at Pantnagar, Uttarakhand. J. Entomol. Zool. Stud. 9(1): 1288-1294.

Kumar S, Das G, Shin HS and Patra JK 2017 Dioscorea spp. (a wild edible tuber): a study on its ethnopharmacological potential and traditional use by the local people of Similipal biosphere reserve, India. Front. Pharmacol. 8(52): 1-17.

Mauti GO, Kasigwa PF and Onguso JM 2020 Antioviposition and reduction of Callosobruchus chinensis Pic. 1902 (Coleoptera: Bruchidae) emergence on Phaseolus vulgaris by Dioscorea sansibarensis powder and its chemical composition. Psyche J. Entomol. 2020(1): 1-6.

Mauti GO, Kasigwa PF, Munissi JJ and Onguso JM 2019a, Evaluation of the repellent effect of Dioscorea sansibarensis Pax (Dioscoreaceae) leaf essential oil against Bruchus chinensis Linnaeus, 1758 (Coleoptera: Bruchidae). Pol. J. Entomol. 88(2): 119-128.

Mauti GO, Kasigwa PF, Munissi JJ and Onguso JM 2019b Chemosensory response of the Phaseolus vulgaris L.(Fabaceae) weevil (Bruchus chinensis
Linnaeus, 1758 (Coleoptera: Bruchidae) to Dioscorea sansibarensis Pax. (Dioscoreaceae) bulbil essential oil. Pol. J. Entomol. 88(2): 183195.

Mishra SK, Macedo LR, Panda SK and Panigrahi J 2018 Bruchid pest management in pulses: past practices, present status and use of modern breeding tools for the development of resistant varieties. Ann. Appl. Biol. 172(1): 4-19.

Mondal OA and Islam A 2008 Toxicity of chloroform extracts of Derris indica Bennet. against Callosobruchus maculatus (F.) adults. Univ. J. Zool. Rajshahi University 27(1): 95-96.

Mustary UH, Nahar A, Rekha SB, Hasan A and Islam N 2020 Screening of Allamanda cathartica L. extracts against stored product pests, Tribolium castaneum (Herbst), Sitophilus oryzae (L.) and Callosobruchus chinensis (L.). J. Entomol. Zool. Stud. 8(5): 414-419.

Odeyemi OO, Masika P and Afolayan AJ 2008 A review of the use of phytochemicals for insect pest control. Afr. Plant Prot. 14(4): 1-7.

Philbert A 2021 Larvicidal potency of Dioscorea sansibarensis leaf extract against vector mosquitoes: Anopheles gambiae and Culex quinquefasciatus. Tanz. J. Sci. 47(2): 655-663.

Price EJ, Wilkin P, Sarasan V and Fraser PD 2016 Metabolite profiling of Dioscorea (yam) species reveals underutilised biodiversity and renewable sources for high-value compounds. Sci. Rep. 6: $1-10$.

Shukla R, Kumar A, Prasad CS, Srivastava B and Dubey NK 2009 Efficacy of Acorus calamus L. leaves and rhizome on mortality and reproduction of Callosobruchus chinensis L. (Coleoptera: Bruchidae). Appl. Entomol. Zool. 44(2): 241-247.

Targett NM, Kilcoyne JP and Green B 1979 Vacuum liquid chromatography: an alternative to common chromatographic methods. J. Org. Chem. 44(26): 4962-4964.

Uyi OO, Udeogwu CC and Rotimi J 2020 Phytochemical constituents and insecticidal efficacy of the root and leaf powders of Mimosa diplotricha and Aspilia africana against Callosobruchus maculates (Fab.) (Coleoptera: Chrysomelidae). J. Appl. Sci. Environ. Manag. 24(4): 645-652. 